\title{
International Spillovers and Cooperation
}

\author{
Emine Boz ${ }^{1} \cdot$ Linda Tesar $^{2}$
}

Published online: 7 February 2020

(c) International Monetary Fund 2020

Policies motivated by national objectives can have far-reaching international consequences in a highly interconnected world. These international externalities provide the basis for policy coordination and multilateral institutions. Backlash against globalization, however, has increased pressure on policymakers to step away from commitments to international cooperation and has undermined support for global institutions. The 19th Jacques Polak Annual Research Conference of the IMF brought together researchers and policymakers to discuss "International Spillovers and Cooperation" on November 1-2, 2018.

In his Mundell-Fleming Lecture, Raghuram G. Rajan (University of Chicago Booth and NBER) discusses the interplay between cross-border capital flows, exchange rates, and incentives for corporate borrowing in capital-receiving countries. Based on his joint work with Douglas W. Diamond (Chicago Booth and NBER) and Yunzhi Hu (University of North Carolina), Professor Rajan argues that easy monetary policy in funding countries increases the expected net worth of firms in capital-receiving countries and their ability to buy assets. Anticipating this higher liquidity for their assets, corporations in capital-receiving countries lever up; at the same time, the expected higher availability of funds in the future reduces the incentive to enhance the pledgeability of their assets. Firms therefore overborrow, and when monetary policy in source countries tightens, receiving-country exchange rates depreciate, and corporate liquidity dries up even if country prospects are sound. Given the externality of capital flows on incentives for corporate governance, Professor Rajan concludes that there might be a rationale for recipient countries to limit exchange rate movements to avoid spillovers from monetary policies in funding countries.

Stephen G. Cecchetti (Brandeis International Business School) and IMF coauthors Tommaso Mancini-Griffoli, Machiko Narita and Ratna Sahay provide

Emine Boz

EBoz@imf.org

Linda Tesar

ltesar@umich.edu

1 International Monetary Fund, Washington, USA

2 University of Michigan, Ann Arbor, MI, USA 
empirical support for the view that US monetary policy has a significant impact on the risk-taking behavior of financial firms ("U.S. or Domestic Monetary Policy: Which Matters More for Financial Stability?"). Covering nearly 1000 financial institutions in 21 countries over 15 years, the study finds that both banks and nonbanks increase leverage following domestic and US monetary policy easing. Importantly, easing in the USA is associated with higher leverage in non-US firms, and in some countries, the response is larger following US monetary policy easing than following domestic easing. As the authors note, this finding suggests that "when business cycles are correlated, domestic and US monetary policies will work together to amplify the swings in financial sector vulnerability."

In a similar vein, C. Bora Durdu (Federal Reserve Board), Alex Martin (MIT), and Ilknur Zer (Federal Reserve Board) focus on the link between US monetary policy and banking crises ("The Role of US Monetary Policy in Banking Crises across the World"). Studying 69 countries over a long historical sample (1870-2010), the authors find that US monetary policy tightening increases the probability of a banking crisis for those countries with direct linkages to the USA, either through trade or through financial exposure of large US dollar-denominated liabilities. The authors argue that if a country is integrated globally, rather than having a direct exposure to the USA, the transmission of monetary policy to the increased likelihood of a banking crisis is weaker. This suggests that there is an important distinction between being tightly linked with the US economy and with more general integration in global markets.

The presence of global spillovers from monetary policy in one market to financial vulnerability in other markets suggests that policymakers face an increasingly complex coordination problem in designing optimal policy. In "Implementable Rules for International Monetary Policy Coordination," Michael B. Devereux (University of British Columbia), Charles Engel (University of Wisconsin) and Giovanni Lombardo (Bank for International Settlements) set an ambitious goal of providing simple policy rules that effectively capture the complex trade-offs facing policymakers in financially integrated economies. To obtain such rules they treat an open-economy DSGE model with financial and nominal frictions as the data generating process and use an extension of SVAR identification techniques. The authors find that monetary policy rules that generate outcomes that are close to those under an optimal rule must include non-traditional factors to capture the trade-off between domestic inflation variability and financial conditions.

The next paper considers the desirability of governments' access to international bond markets. "On the Welfare Losses from External Sovereign Borrowing" by Mark Aguiar (Princeton University), Manuel Amador (Federal Reserve Bank of Minneapolis and University of Minnesota) and Stelios Fourakis (University of Minnesota) evaluates the costs and benefits of sovereign debt when private individuals discount the future at a different rate from their government. Using a range of models that are commonly used to analyze sovereign debt, they find that in the case of such a disagreement in preferences, the private sector may actually prefer that the government has no access to external borrowing. The results depend on the maturity of debt as well as the costs incurred in the event of a default. In general, their findings provide a counterweight to proposals that are designed to ease market access for sovereign borrowers.

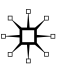


Adding to the rich empirical literature on fiscal multipliers, Alan Auerbach (University of California, Berkeley), Yuriy Gorodnichenko (University of California, Berkeley), and Daniel Murphy (University of Virginia) focus on spillovers operating through government spending. They use information on US defense contracts to identify local fiscal multipliers and spillovers to bordering regions ("Local Fiscal Multipliers and Fiscal Spillovers in the USA"). Their key finding is that a dollar of defense spending in a city increases GDP in that city by a dollar, increases labor earnings by $\$ 0.35$, and generates an increase in employment. Further, the authors find positive effects on nearby locations, increasing GDP, and earnings. Geographical spillovers appear to dissipate fairly quickly with distance. The authors interpret their evidence as pointing to the relevance of Keynesian-type models that feature excess capacity.

"The Economics and Politics of Revoking NAFTA" by Raphael A. Auer (Bank for International Settlements and CEPR), Barthélémy Bonadio (University of Michigan), and Andrei A. Levchenko (University of Michigan, NBER, and CEPR) provides a quantitative assessment of both the aggregate and the distributional effects of revoking NAFTA. Using a multi-country, multi-sector, multi-factor model of world production and trade with global input-output linkages, the analysis suggests that revoking NAFTA would reduce US welfare by about $0.2 \%$, and Canadian and Mexican welfare by about $2 \%$. The distributional impacts of revoking NAFTA across workers in different sectors are an order of magnitude larger in all three countries, ranging from -2.7 to $2.23 \%$ in the USA. Their analysis has significant political implications as well: Using information on the geographic distribution of sectoral employment, the authors compute average real wage changes in each US congressional district, Mexican state, and Canadian province. This analysis reveals that districts that voted more for Trump would on average experience greater real wage reductions in the event NAFTA is revoked.

In the final paper of this issue ("At A Cost: the Real Effects of Transfer Pricing Regulations"), Ruud De Mooij and Li Liu (both IMF) estimate spillovers resulting from the unilateral adoption of transfer pricing regulations (TPRs) on real investment by multinational corporations (MNCs). The authors use a quasi-experimental research design and exploit unique panel data on domestic and multinational companies in 27 countries during 2006-14. They find that MNC affiliates reduce their investment by over 11 percent following the introduction of TPRs. Interestingly, the analysis reveals no significant reduction in total investment by the MNC group, suggesting that these investments are most likely shifted to affiliates in other countries.

We think this issue covers a wide range of important questions about the linkages between markets and spillovers across national, regional as well as local boundaries. The issue also provides insight into how policy must adapt to improve welfare in an increasingly interconnected world. We thank all the authors for their valuable contributions to this issue and hope that you will enjoy reading it.

Publisher's Note Springer Nature remains neutral with regard to jurisdictional claims in published maps and institutional affiliations. 